\title{
correspondence
}

\section{Short term contracts}

SIR,-It is sad that three recent articles (23 November, page 310; 28 December, pages 743 and 745 ) on the difficulties facing research workers in universities have induced little dialogue in your correspondence columns. It has been our association's experience that there are at least two reasons for such a lack of response: (a) research scientists are often isolated in departments with a high percentage of tenured staff and think that protestation would have little or no effect; (b) many fear that if they do step out of line and "speak out" they will not only jeopardise their present job but will find it even harder to secure another. Presumably, it is because of this that the present appalling situation has been allowed to develop. We therefore would like to appeal to all researchers to start thinking positively, join a union and become active in it, join our association (if appropriate), or form an association and write to your MP, asking for an inquiry. We demand to have a career structure in research with some prospect of security so that a PhD will come to be regarded again as an attribute and not a liability!

ARLEEN UNGer

ARMS, London, UK.

\section{Sollas and the Sherborne bone}

SiR,-I would like to correct the record of the Sherborne engraved bone controversy, unfortunately misrepresented in Dr L. B. Halstead's account of the late Professor Douglas's tape-recording linking Sollas with the Piltdown hoax (2 November, page 11). Douglas's story reveals nothing fresh except his own assumption that Sollas kept quiet about a 'hoax' at Sherborne School (Dorset) so that Smith Woodward might make a fool of himself; the rest is a tendentiously garbled summary of Bayzand's evidence against the bone in Nature 117, 233; 1926, confounded with facts stated by Smith Woodward himself (Nature, 117, 86; 1926).

Dr K. P. Oakley established in 1957 that the piece of bone was ancient and consistent with an Upper Pleistocene date. It is clear to the naked eye that it is semi-fossilised, as Smith Woodward claimed in his reply (Nature 117, 86) to Sollas's denunciation in Ancient Hunters (1924). Sollas (Nature 117, 233) was nonplussed by this claim and attempted to parry it with an ignorant remark betraying that he had never seen the object. Neither had Bayzand! Had he done so he could not have left Sollas in ignorance of a fact so vital to any assessment of a schoolboy hoax, or failed to investigate an ostensible fake of extraordinary ingenuity, as his wholly imprecise charge shows. It is impossible to resist the conclusion that Bayzand heard a story, true or false, and simply did nothing at all-until 1914 , as he himself tells us, when
Smith Woodward's paper appeared (Q. Jl. Geol. Soc., 70, 100-2).

It is generally supposed that Sollas and Bayzand were left with the last word, for Douglas evidently believed them, as did the late Joseph Fowler of Sherborne, whose exhaustive but uncompleted research led to my own interest in the affair. There was, however, a third letter in Nature $(117,341-2 ; 1926)$ only weeks later, from the supposed hoax victim, R. E. Steel, who began by apologising for Bayzand's having been misled by senior boys who had been unable to credit such a find by two 14-year-olds, Arnaldo Cortesi and Philip Grove, in their first weeks at the school. His account of the circumstances of discovery, corroborated by a former pupil who had recognised the character of the engraving and prevented Cortesi from throwing it into the day-room fire, and the aptness of the alleged site (thereupon efficiently investigated by Steel), are entitled to respect.

The question remains whether there was anything more than school rumour in the story Bayzand treated so casually but with such disastrous consequences for a potentially rare and interesting find. Was the engraving nevertheless faked. and if so, whence came the material and expertise? One can imagine Douglas's answer-one that would at least make sense of his otherwise forced analogy between Sherborne and

Piltdown-but I hope shortly to deal more fully, in Antiquity, with this and other aspects of this curious tale.

$$
\text { R. A. H. FARRAR }
$$

Roval Commission on Historical Monuments,

Lonton, $U K$.

\section{Seveso}

SIR,-Professor Garattini and Dr Manara of the Istituto di Ricerche

Farmacologiche Mario Negri, Milan, have accused me of underestimating the possible damage to human health caused by the Seveso accident ( 7 December, page 556).

I took on the assessment of the damage to health caused by the accident because I had been personally involved from the beginning in protection and prevention measures for the injured and for those still exposed.

I played an important role in the decision to evacuate the population of Seveso. This has been stated in several books on Seveso and in official documents in my possession. I never expected that readers of my papers would accept on sight my assessment of the consequences of the accident on the health of the population, and I have therefore always based my reports and conclusions on documents ${ }^{1-10}$ which cannot be accused of prejudice in my favour. The great majority of these authors are either members of the Epidemiological Medical Commission of the Lombardy Region in Milan (of which Professor Garattini has been a member since its beginning) with responsibility for the health surveillance of the population, or of the Advisory Scientific Committee to the Italian Government in Rome for the Seveso accident (Commissione Cimino).

They have been (and still are) confronted with one of the most difficult and tricky problems in medicine. They have mastered the emergency with courage, skill and competence. The dermatological screenings carried out by them on 32,000 schoolchildren have no precedent in the history of clinical toxicology. I trust their reports to be accurate, meticulous and unbiased.

Nevertheless I may have overlooked or missed data available to Professor Garattini and Dr Manara which would prove me wrong. I therefore ask Professor Garattini and Dr Manara to make any such data known immediately, because only then (and not by saying that I am biased) will it be possible to evaluate the damage.

About 5.000 people are still exposed to levels of TCDD which, while admittedly lower than those of past cases of occupational exposure, could represent a potential risk. If my conclusions are wrong, we have a moral obligation to take protective measures immediately to prevent any further damage to this population.

\section{G. RegGiani}

\section{Hoffmann-La Roche}

1. Environmental Health Criteria for Tetrachlorodibenzodioxine.

2. Giovanardi, A. Proceedings of the Experts Meeting on the problems raised by TCDD pollution. Milan, 30 September-1 October 1976.

4. Fara, G. M. ibid. di salute nella zona inquinata da TCDD. Quaderno di Documentazione 28.5.1977.

5. Fara, G. M. Seveso: Studies on teratogenic and other chronic effects of chemical pollutants following an accident in a chemical plant. Symposium on Detection of Teratogens. 5th Int. Conference on Birth Defects. Montreal, 21 August 1977

6. Pocchiari. F. Accidental TCDD contamina tion in Seveso (Italy). Epidemiological aspects. Meeting on the long-term hazard of polychlorinated dibenzodioxins and dibenzofurans. International Agency for Research on Cancer. Internal Technical Report, Lyon, January 1978

7. Pocchiari, F. Human health effects from accidental release of TCDD at Seveso (Italy). International conference on health aromatic hydroSciences.

8. Puccinelli, et al. Skin disorders in the Seveso area after the accident at the Icmesa plant. Reports to the Chloracne Panel of the Commission of the European Communities. Directorate for Employment and Social Afairs. Division 1977 January and May 1978 .

9. Dioguardi N Critical considerations two years after the accidental pollution of years after the accidental pollution of 1978". Analysis and evaluation of the consequences of pollution by TCDD and of consequences of pollution by TCDD and of the Icmesa disaster. 2 July 1978.

10. Report of the Italian Parliamentary Commission of Inquiry. Chapter 2, pp. 145-181. The after effects of the incident of 10 July, 1976 on the health of the population exposed to the risk of contamination. Rome, July 1978. 